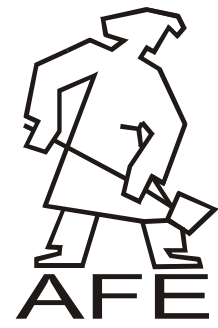

\title{
Preliminary Research on Granulation Process of Dust Waste from Reclamation Process of Moulding Sands with Furan Resin
}

\author{
J. Kamińska ${ }^{a *}$, J. Dańko ${ }^{a}$ \\ ${ }^{a}$ AGH University of Science and Technology, Faculty of Foundry Engineering, Reymonta 23, \\ 30-059 Krakow, Poland \\ * Corresponding author: e-mail: kaminska@agh.edu.pl
}

Received 16.04.2012; accepted in revised form 02.07.2012

\begin{abstract}
The results of investigations of the granulation process of foundry dusts generated in the dry mechanical reclamation process of used sands, where furan resins were binders are presented in the paper. Investigations concerned producing of granules of the determined dimensions and strength parameters.

Granules were formed from the dusts mixture consisting in 50 mass\% of dusts obtained after the reclamation of the furane sands and in 50 mass \% of dusts from sands with bentonite. Dusts from the bentonite sands with water were used as a binder allowing the granulation of after reclamation dusts from the furane sands.

The following parameters of the ready final product were determined: moisture content $(\mathrm{W})$, shatter test of granules $(\mathrm{Wz})$ performed directly after the granulation process and after 1,3,5,10 days and nights of seasoning, water-resistance of granules after 24 hours of being immersed in water, surface porosity ep and volumetric porosity ev. In addition the shatter test and water-resistance of granulate dried at a temperature of $105 \mathrm{oC}$ were determined.

Investigations were performed at the bowl angle of inclination 45o, for three rotational speeds of the bowl being: 10, 15, $20 \mathrm{rpm}$.

For the speed of $10 \mathrm{rpm}$ the granulation tests of dusts mixture after the preliminary mixing in the roller mixer and with the addition of water-glass in the amount of $2 \%$ in relation to the amount of dust were carried out.

The obtained results indicate that the granulator allows to obtain granules from dusts originated from the reclamations of moulding sands with the furane resin with an addition of dusts from the bentonite sands processing plants.
\end{abstract}

Key words: Moulding sands, After reclamation dust, Granulation, Environment protection.

\section{Introduction}

Analysis of a structure and amount of wastes generated in foundry plants provides information concerning waste management tests by their recycling or reclamation of some components. Blast furnace dusts and slag from metal melting processes can be reused in the foundry practice or in other industry branches $[1,2]$.
In spent sands dry reclamation systems even up to 10 mass \% of after reclamation dusts are generated. In these dusts significant amounts of binders or clays, removed from sand grains or products of sand grinding, are accumulated [3-6]. In case of spent moulding sands with resins these dusts have often high ignition loss values (above $30 \%$ ), which indicates a large content of combustible parts [7].

Storing of these type of wastes (dusts) requires properly protected dumping grounds, which generates high costs [8]. The possibility of management of after reclamation dusts depends 
on their properties and on the way of their form transformation. The most often their chemical and phase composition, grain size, volatile parts and silica content, $\mathrm{pH}$ and environment impact are taken into account [9].

Loose self-hardening sands with furan resins are still the most often applied. They can be used for making moulds as well as cores - of various sizes and shapes, and also for castings from all casting alloys [10]. Dusts originated from such moulding sands reclamation are difficult for loading and transportation due to their high dusting degree. Therefore their previous granulation can be one of the management tendency [8].

\section{Program of own investigations}

The chemical composition of granulated dusts is listed in Table 1. Dusts mixture consisting of 50 mass $\%$ of dusts from moulding sands with bentonite (Tab. 1a) and 50 mass \% of dusts after the furan sand reclamation (Tab $1 \mathrm{~b}$ ) was granulated in the prototype bowl granulator [11].

Table 1.

Chemical composition of granulated dusts: a - Dust from sands with bentonite, $\mathrm{b}$ - Dust from sands with furan resin a)

\begin{tabular}{||c|c|}
\hline Element & $\begin{array}{c}\text { Concentration } \\
{[\%]}\end{array}$ \\
\hline $\mathbf{A l}$ & 5,64 \\
\hline $\mathbf{C}$ & 16,80 \\
\hline $\mathbf{C a}$ & 0,82 \\
\hline $\mathbf{F e}$ & 1,07 \\
\hline $\mathbf{K}$ & 0,69 \\
\hline $\mathbf{M g}$ & 1,17 \\
\hline $\mathbf{N a}$ & 1,26 \\
\hline $\mathbf{S}$ & 0,24 \\
\hline $\mathbf{S i}$ & 24,74 \\
\hline & $\mathbf{C o n c e n t r a t i o n}$ \\
& {$[\mathbf{p p m}]$} \\
\hline $\mathbf{B i}$ & $<6,00$ \\
\hline $\mathbf{O}$ & 42,15 \\
\hline $\mathbf{P b}$ & 37,00 \\
\hline $\mathbf{S b}$ & $<1,00$ \\
\hline
\end{tabular}

\begin{tabular}{||c|c|}
\hline Element & $\begin{array}{c}\text { Content of } \\
\text { the } \\
\text { component } \\
{[\text { mass \%] }}\end{array}$ \\
\hline $\mathbf{A l}_{\mathbf{2}} \mathbf{O}_{\mathbf{3}}$ & 4,30 \\
\hline $\mathbf{C a O}$ & 0,30 \\
\hline $\mathbf{C l}$ & 0,011 \\
\hline $\mathbf{F e}_{\mathbf{2}} \mathbf{O}_{\mathbf{3}}$ & 2,43 \\
\hline $\mathbf{K}_{\mathbf{2}} \mathbf{O}$ & 1,25 \\
\hline $\mathbf{M g O}_{\mathbf{2}}$ & 1,07 \\
\hline $\mathbf{N a}_{\mathbf{2}} \mathbf{O}$ & 0,27 \\
\hline $\mathbf{S i O}_{\mathbf{2}}$ & 85,60 \\
\hline $\mathbf{S O}_{\mathbf{3}}$ & 0,12 \\
\hline $\mathbf{Z r O}_{\mathbf{2}}$ & 1,13 \\
\hline \multicolumn{2}{|c}{} \\
\hline
\end{tabular}

The dusts mixture, of an amount of $10 \mathrm{~kg}$, was supplied by portions on the granulating bowl and sprinkled with water (16mass \% in relation to the dust amount). The bowl was rotating successively with the given speeds (10,15 and $20 \mathrm{rpm})$, at the inclination angle of $45^{\circ}$. A wetted material was agglomerating in the bowl forming granules of diameters varying from 3 to $60 \mathrm{~mm}$.

The results of physical and chemical as well as strength properties of dusts from the furan sand reclamation and from sand with bentonite are already published $[12,13]$.

\section{Results}

As the first stage of investigations the optimal amount of bentonite dusts added to the after reclamation furan dusts to obtain the best dust mixture undergoing the granulation process was experimentally determined. The bentonite dust addition was changing every $5 \%$ in the range from 25 to $50 \%$. The chemical reaction change (Fig. 1) and ignition loss (Fig. 2) of ready granules in dependence of the composition of the dust mixture is presented below. It can be noticed that at an increased addition of bentonite dusts the acidity of the mixture decreases. At the determined optimal composition $(50 / 50 \%) \mathrm{pH}$ value is near 7 , thus indicating the neutral character of the mixture.

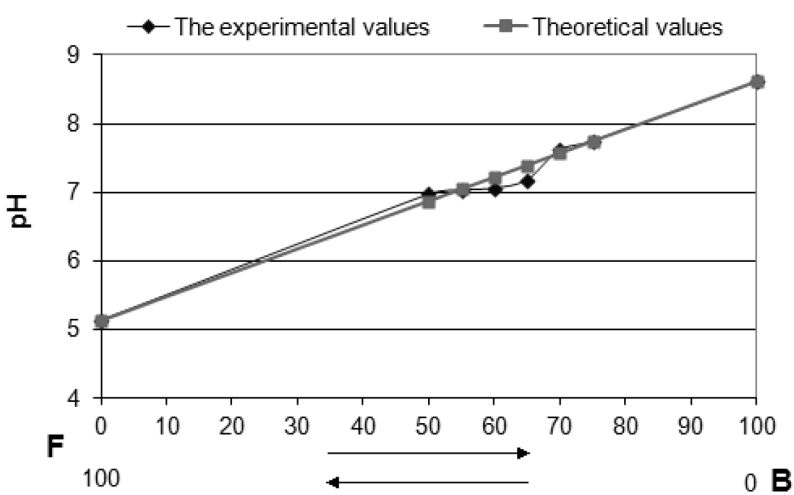

Fig. 1. pH value of granules, obtained from the dust mixture in dependence of its composition; B - dust from sands with bentonite, $\mathrm{F}$ - dust from sands with furan resin

An opposite dependence character is observed for ignition losses. An increased addition of bentonite dusts causes an increased ignition loss due to coal dusts.

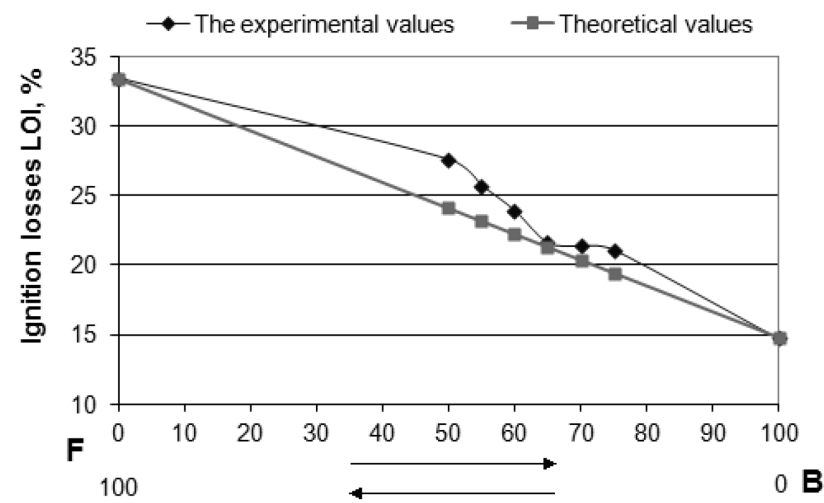

Fig. 2. Ignition loss of granules obtained from a dust mixture, in dependence of its percentage composition; notations as in Fig.1

When the optimal mixture composition was determined the granulation process was performed. An example of grain size of granules is shown in Figure 3. 

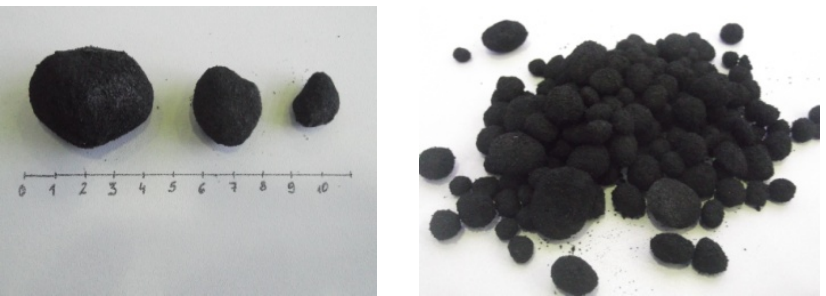

Fig. 3. Granulate fractions, granulator rotational speed - $10 \mathrm{rpm}$, angle of inclination $-40^{\circ}$, scale in $\mathrm{cm}$

The results of granules shatter tests at the granulator bowl rotational speed being $10 \mathrm{rpm}$, is presented in Figure 4. In case of granules tested after one shatter a constant strength decrease accompanies a seasoning time prolongation. The lowest strength is obtained after 10 days of seasoning. In the case of strength obtained after 3 shatters up to the $5^{\text {th }}$ day the strength decrease is observed with the seasoning time prolongation. However, when this time is exceeded the granules strength increases.

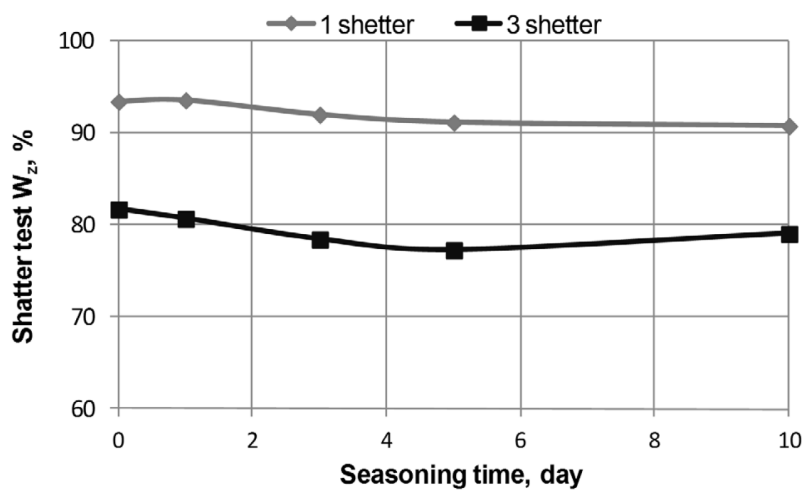

Fig. 4. Dependence of shatter tests value on the granules seasoning time, rotational speed of the granulator disk: $10 \mathrm{rpm}$, angle of inclination of the disk: $45^{\circ}$

The dependence of the granules shatter test on the seasoning time, for the rotational speed being $15 \mathrm{rpm}$, is presented in Figure 5. The highest shatter test after 1 and 3 shatters is characterising the raw (initial) granular material and the granulate after 10 days of seasoning. The initial seasoning time causes a strength decrease.

An analogous dependence of shatter tests on the seasoning time, for the speed being $20 \mathrm{rpm}$ is presented in Figure 6 . The initial granular material and the one after 10 days of seasoning obtains, after the first shatter, practically $100 \%$ of strength. After being shattered on a steel plate granules are not disintegrated. The lowest strength of granules is after 5 days of seasoning. A similar pathway obtains the strength curve after 3 shutters and 3 days of seasoning.

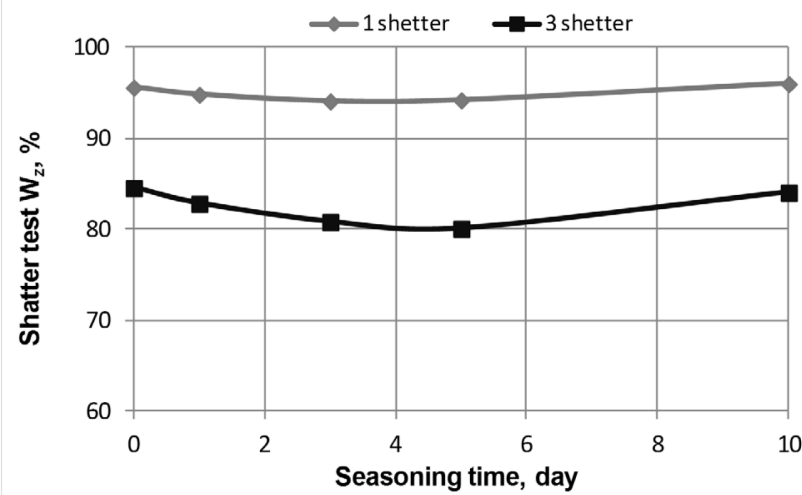

Fig. 5. Dependence of shatter tests value on the granules seasoning time, rotational speed of the granulator disk: $15 \mathrm{rpm}$, angle of inclination of the disk: $45^{\circ}$

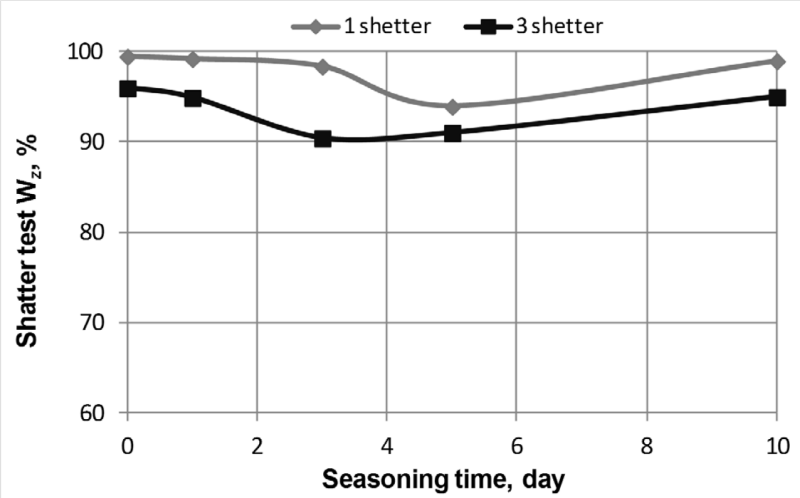

Fig. 6. Dependence of shatter tests value on the granules seasoning time, rotational speed of the granulator disk: $20 \mathrm{rpm}$, angle of inclination of the disk: $45^{\circ}$

Figure 7 presents the influence of the seasoning time on the granules water content. At all rotational speeds of the granulator bowl, the increase of the granules seasoning time causes the decrease of their water content as a result of drying. The curve, for the speed of $20 \mathrm{rpm}$, is nearly linear.

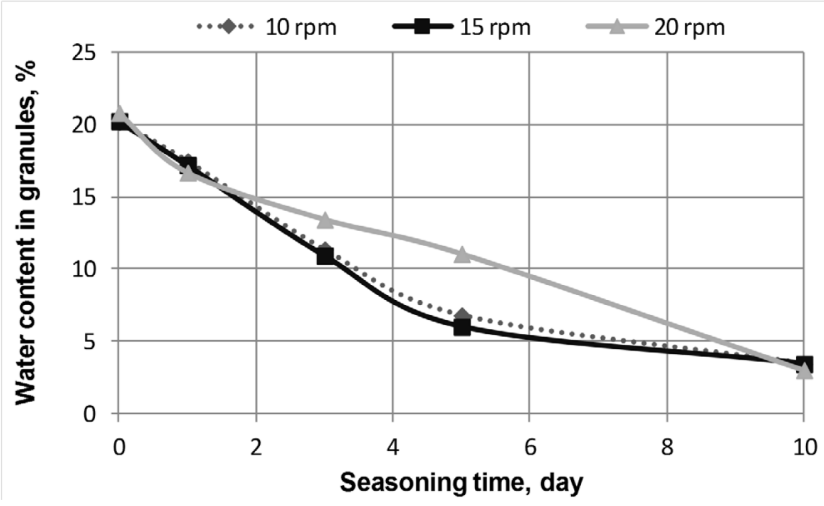

Fig. 7. Influence of the seasoning time on the water content in granules 
The dependence of the shutter tests of granules dried at a temperature of $150^{\circ} \mathrm{C}$ for 3 hours on the rotational speed is shown in Figure 8. For the granules after 1 shutter as well as after 3 shutters an increase of the granulator bowl rotational speed causes an increase of strength.

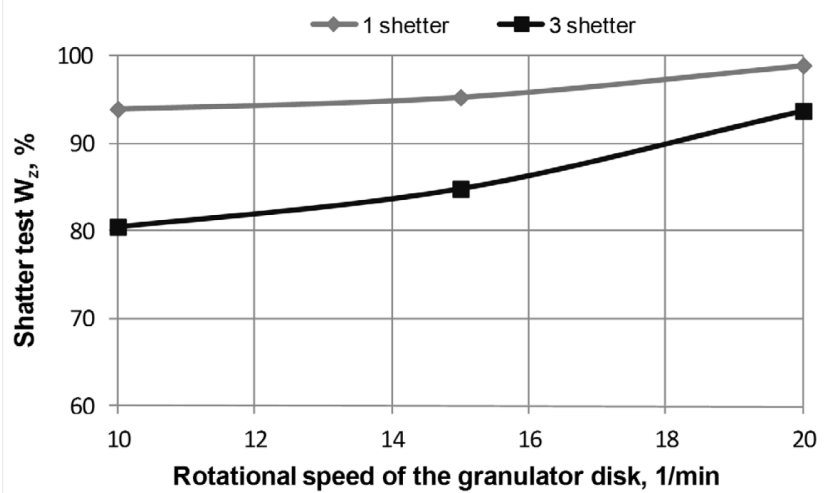

Fig. 8. Dependence of the shutter test on the granulator bowl rotational speed for granules dried at temp. $150^{\circ} \mathrm{C} / 3 \mathrm{~h}$

The results of surface areas and volumetric measurements of granules are presented in Figure 9. An initial increase of the bowl speed from 5 to $10 \mathrm{rpm}$ causes a significant decrease of granules dimensions. Further increases of this speed does not cause large changes. The volumetric measurement was aimed at the determination of the approximate density of granules. Increasing the granulator bowl rotational speeds does not cause differences in the density of granular materials.

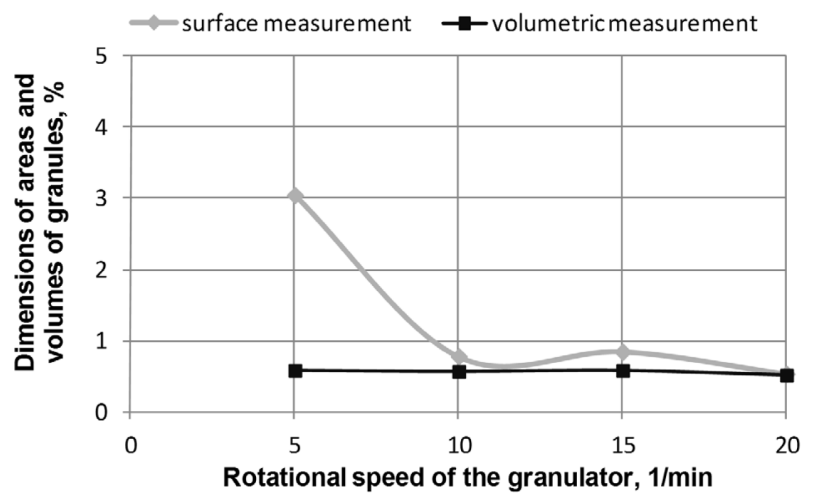

Fig. 9. Dimensions of areas and volumes of granules in dependence on the granulator bowl rotational speed

For the granulator bowl rotational speed being $10 \mathrm{rpm}$ granulation tests were also carried out for the mixture of dusts after their preliminary mixing in the roller mixer (mixing time 3 minutes, without preliminary moistening) and with an addition of water-glass in an amount of $2 \%$ in relation to the dust amount.

Shutter tests curves after 1 shutter are presented in Figure 10, while after 3 shutters in Figure 11. Both, after 1 and 3 shutters, highest strength characterise the granules from dusts mixture with an addition of water-glass, while the lowest the pure granules from the granulator without any additions and preliminary mixing. In case of the shutter test after 1 shutter the increase of the seasoning time causes the decrease of the granules strength. In case of the shutter tests after 3 shutters the initial increase of the granule seasoning time causes a decrease of their strength. After 10 days of seasoning only an insignificant strength increase is observed.

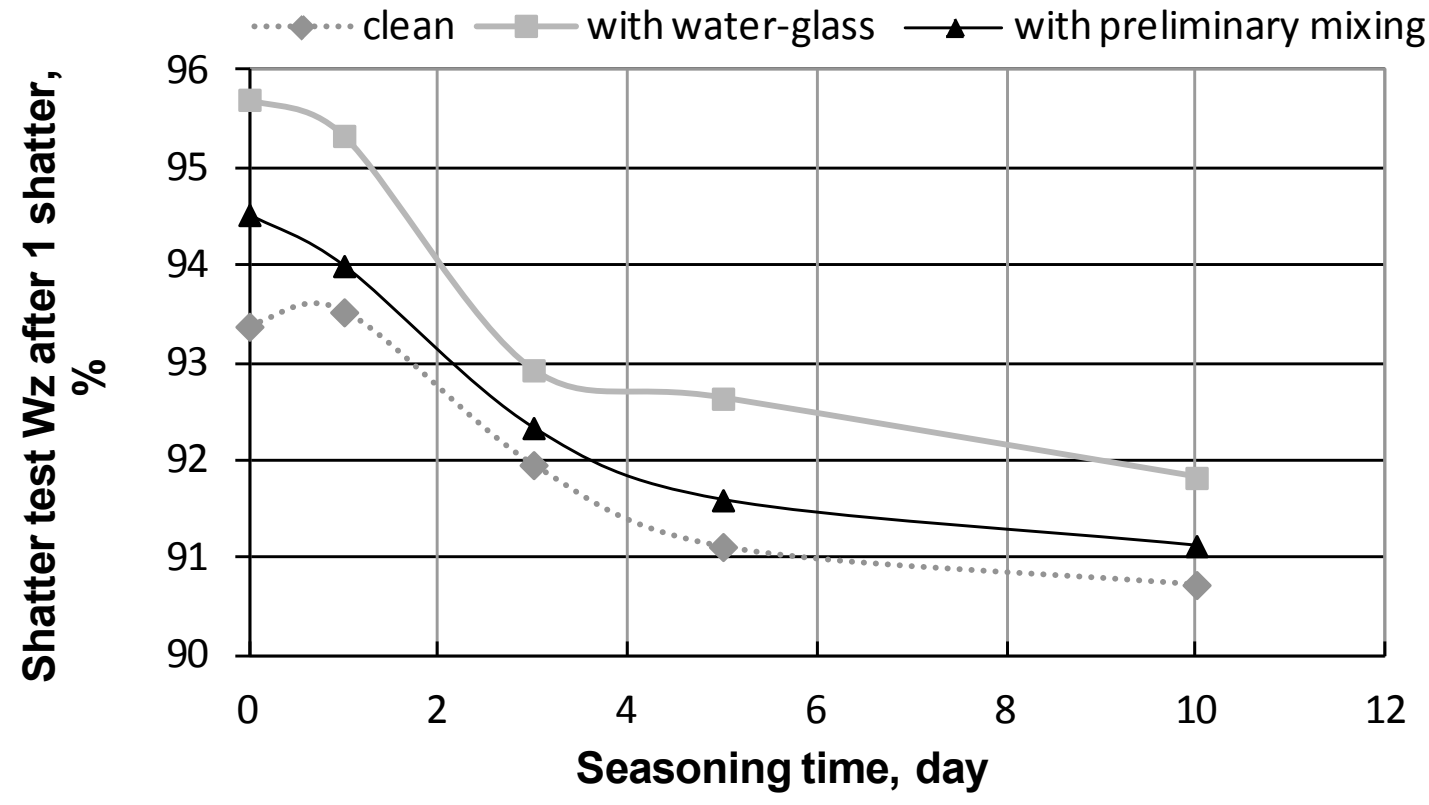

Fig. 10. Dependence of the shatter tests after 1 shatter on the granules seasoning time, rotational speed of the granulator disk: $10 \mathrm{rpm}$, angle of inclination of the disk: $45^{\circ}$ 


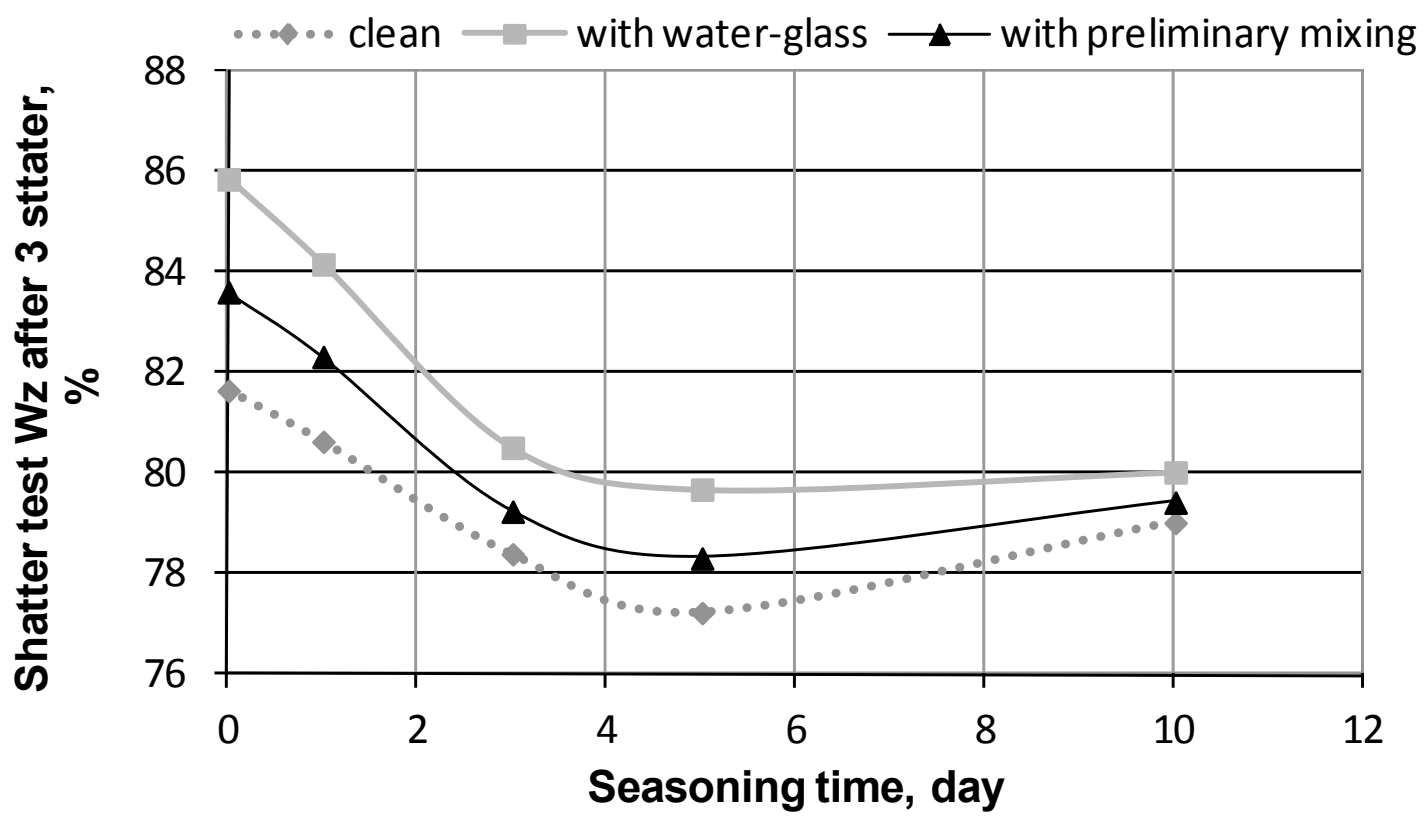

Fig. 11. Dependence of the shatter tests after 3 shatter on the granules seasoning time, rotational speed of the granulator disk: $10 \mathrm{rpm}$, angle of inclination of the disk: $45^{\circ}$

The influence of the seasoning time on the water content in granules is shown in Figure 12. Curves are analogous to the strength curves after 1 shatter, which means that a prolongation of the seasoning time of granules causes their water content decrease. It can be noticed that pure granules have the highest moisture content during the whole seasoning period.

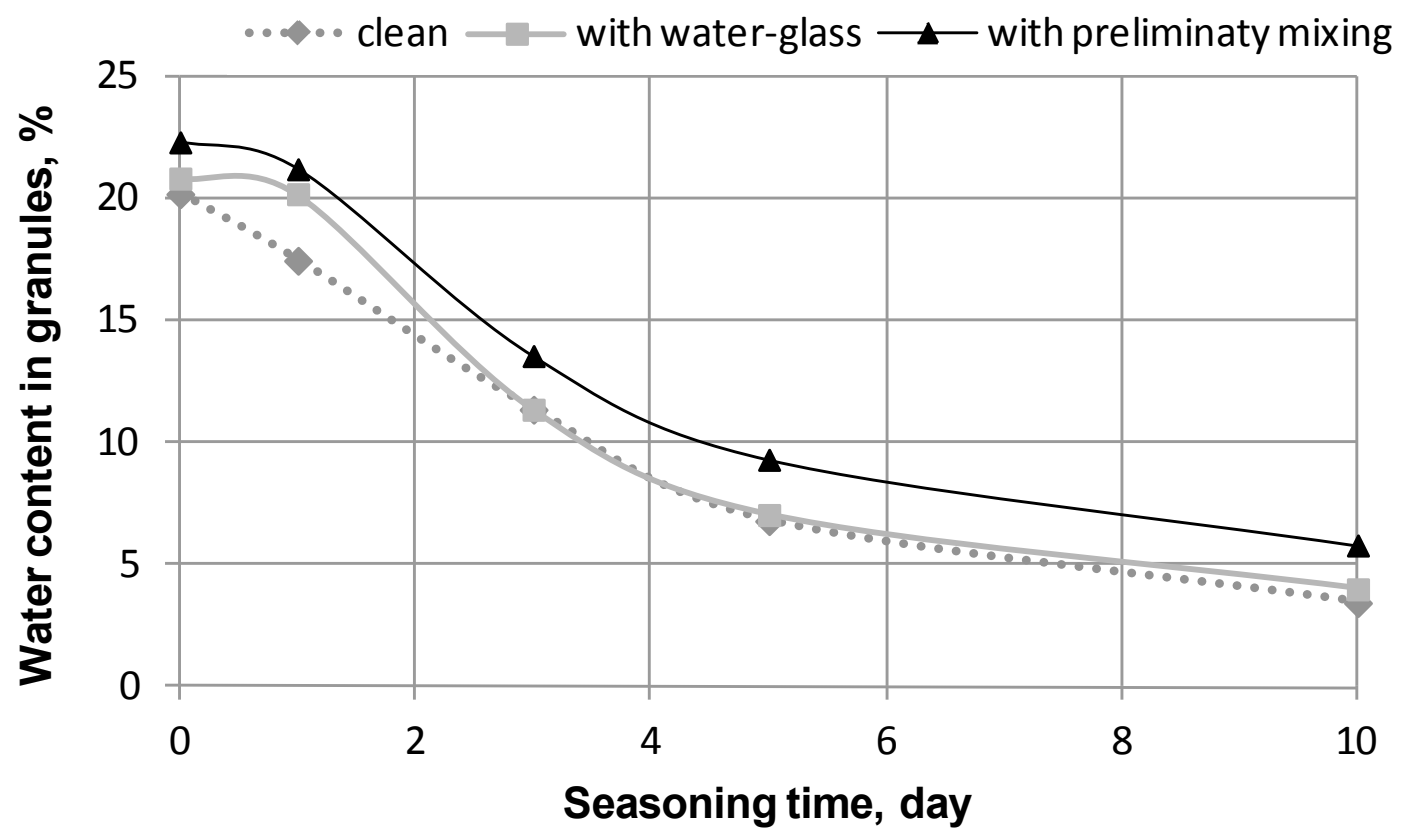

Fig. 12. Influence of the seasoning time on water content in granules, rotational speed of the granulator disk: $10 \mathrm{rpm}$, angle of inclination of the disk: $45^{\circ}$ 


\section{Conclusions}

The obtained results indicate that the applied granulator allows to achieves granules from dusts originated from the moulding sands with furane resin reclamation with an addition of dusts from bentonite moulding sands reclamation.

The determined optimal composition of dusts mixture: 50 mass $\%$ of dusts after the furane moulding sand reclamation and 50 mass $\%$ of dusts from the bentonite moulding sands, enables the formation of granules of the proper dimensions and strength.

For the granulator angle of inclination being $45^{\circ}$ the optimal rotational speed of the bowl should be $20 \mathrm{rpm}$. At this speed the granules are characterised by the highest shatter test value.

The preliminary mixing of dusts, before the granulation process, and the water-glass addition to the dust mixture caused increase of the shatter test value at simultaneous decreasing their moisture content. However, on account of only very small strength increase (approximately $4 \%$ ), reasons of the granulation process modification are not justified, the more so as this causes the costs increase.

\section{Acknowledgements}

The study was performed as the Project co-financed by the European Fund of Regional Development within the Operational Program of Innovative Economy,

No. WND-POIG.01.03.01-12-007/09.

\section{References}

[1] Baricowá D., Pribulowá A. \& Demeter P. (2010). Comparison of possibilities the blast furnace and cupola slag utilization by concrete production. Archives of Foundry Eingineering 10(2), $15-18$.
[2] Pribulowá A., Baricowá D., Futaš P. \& Gengel' P. (2010). Possibilities of pelletizing and briquetting of dust from casting grinding. Archives of Foundry Eingineering 10(2), 123-126.

[3] Dańko R. (2011). Innovative developments in sand reclamation technologies. Metalurgija - Metallurgy 50(2), 93-96.

[4] Dańko R. \& Holtzer, M. (2010). Moulding sands grain size investigations by means of the laser method of measurement. Archives of Metallurgy and Materials 55(3), 787-794.

[5] Dańko R., Holtzer, M. \& Dańko, J. (2011). Reclamation of alkaline spent moulding sands of organic and inorganic type and their mixtures. Archives of Foundry Engineering 11(4), 25-30.

[6] Dańko, R. (2009). Analysis of effectiveness of used sands reclamation treatment - in various technological devices. Archives of Foundry Engineering 9(4), 31-36.

[7] Dańko, R. (2010). Experiences gathered during reclamation of used water glass and bentonite sands in extra low and ambient temperature. International Journal of Cast Metals Research 23(2), 92-96. DOI: 10.1179/174313309X451270

[8] Praca zbiorowa (2009). Możliwości ograniczenia i metod zagospodarowania odpadów $\mathrm{z}$ procesów odlewniczych. Kraków: Wydawnictwo Naukowe AKAPIT.

[9] Dańko J., Holtzer, M., Dańko, R. \& Grabowska, B. (2008). Analiza i struktura odpadów z krajowych odlewni. Archives of Foundry Engineering, vol. 8, special issue 2/2008, pp. 5-9.

[10] Lewandowski, J. L. (1997). Tworzywa na formy odlewnicze. Kraków: Wydawnictwo Naukowe AKAPIT.

[11] Kamińska, J. \& Skrzyński, M. (2011). Physical, chemical and strength properties of dust from the bentonite sands treatment plants. Metallurgy and Foundry Engineering 37(2), 189-195.

[12] Kamińska, J. (2011). Dean's Grant, No 15.11.170.417.

[13] Wykorzystanie nowoczesnych technologii regeneracji zużytych mas formierskich do opracowania koncepcji i wykonania innowacyjnego regeneratora wibracyjnego (2009-2012). No WND-POIG.01.03.01-12-007/09-00. 